\title{
OSOBY STARSZE W SYSTEMIE OCHRONY ZDROWIA
}

Zjawisko starzenia się społeczeństw należy do istotnych problemów współczesnych czasów. Polega to na ciągłym wzroście liczby ludzi w podeszłym wieku w ogólnej liczbie ludności żyjącej w poszczególnych krajach. Od początku dwudziestego stulecia trwa proces wydłużania się ludzkiego życia, a równocześnie spada liczba urodzeń. Szacuje się, że kraje rozwijające się (to one są głównie dotknięte tym problemem demograficznym) w 2030 r. będą skupiać $2 / 3$ światowej populacji osób starszych. Kraje Unii Europejskiej znajdują się wśród 50 najstarszych demograficznie państw świata. Według ekspertów Ministerstwa Spraw Społecznych i Ekonomii ONZ od pewnego czasu ludzkość kontynuuje przejście od stanu wysokiego współczynnika urodzeń i zgonów do stanu niskiego współczynnika urodzeń i zgonów. Efektem tego jest duża liczba i wysoki odsetek ludzi starych. Tak dynamicznego i szerokiego wzrostu „starszyzny” nie zaobserwowano dotąd $\mathrm{w}$ historii cywilizacji ${ }^{1}$. Taka sytuacja stanowi wyzwanie dla wielu państw (w tym Polski), które zmuszone sa dostosować dotychczas istniejący system prawno-ekonomiczny do potrzeb zmieniającego się świata. Problem ten dotyka szczególnie systemu ochrony zdrowia.

Celem niniejszego artykułu jest odpowiedź na pytanie, w jakim stopniu obecna organizacja systemu ochrony zdrowia odpowiada faktycznym potrzebom zdrowotnym osób starszych. W artykule definiuje się starość, przedstawiając również towarzyszące jej objawy, stan zdrowia osób starszych, najczęściej występujące choroby wieku starczego i ich wpływ na aktywność psychospołeczną seniorów. Analizie poddana zostanie także opieka geriatryczna, jako najlepsze podejście w leczeniu osób starszych, szczególnie w aspekcie prawnym jej funkcjonowania. Artykuł przedstawia także zagadnienie profilaktyki gerontologicznej oraz edukacji zdrowotnej do i w starości jako sposobów poprawy sytuacji zdrowotnej osób starszych.

\section{ETOS STAROŚCI}

Ludzie starsi od wieków cieszyli się szacunkiem i uznaniem. W społeczeństwach prehistorycznych pełnili funkcję nośnika norm społecznych, zwyczajów i tradycji. Do dzisiaj zresztą stanowiska mężów stanu i przywódców politycznych piastowane sa przez osoby starsze, w czasie ich późnej dorosłości.

${ }^{1}$ Z. Szarota, Starzenie się i starość w wymiarze instytucjonalnego wsparcia, Kraków 2010, s. 45-48. 
Szacunek do osób starszych wywodzi się też z modelu przyjętego w feudalizmie, wynikał on z godności państwowych pełnionych przez seniorów oraz zgromadzonego przez nich majątku. Pewien etos starości wykształcił się szczególnie w społeczeństwach tradycyjnych - ,,seniorzy symbolizowali ciągłość doświadczeń pokoleń i wzmacniali poczucie własnej wartości grup społecznych"2. Paradoksalnie, wydłużenie czasu życia przyniosło dewaluację starości. „Wraz z postępem medycyny oraz rozwojem przemysłu spadła użyteczność starszych ludzi [...]. Społeczeństwo zinstytucjonalizowało tę zmianę, wprowadzając obowiązek przejścia na emeryturę" ${ }^{3}$. Współcześnie mamy do czynienia ze zdegradowanym obrazem starości, pełnym stereotypów o negatywnym zabarwieniu zarówno w aspekcie biologicznym, jak i psychospołecznym. Marginalizacja starości jest usankcjonowana działalnością (a właściwie zaniechaniem) państwa. Jest to szczególnie widoczne w sektorze ochrony zdrowia, w którym seniorzy sa największa grupa świadczeniobiorców - i jedną z najbardziej dyskryminowanych. Polityka społeczna krajów zachodnich sprowadza problem starości populacji do wzrastających kosztów zabezpieczenia społecznego i opieki długoterminowej. „Państwa dążą do zdjęcia z siebie odpowiedzialności za finansowanie tych obszarów, które jednocześnie sa odpowiedzialne za strukturalną zależność człowieka starszego od sektora publicznego" ${ }^{4}$.

\section{DEFINICJA STAROSCI}

Starość to końcowa faza życia rozpoczynająca się wraz z osiagnięciem ,,progu starości”, który wyznaczaja: typowe zmiany biologiczne i psychiczne, zadania rozwojowe, krytyczne zdarzenia życiowe oraz typowe role społeczne $^{5}$. Najczęściej jednak za umowny próg starości przyjmuje się wiek metrykalny ustalony na podstawie daty urodzenia. Jest on łatwiejszy do ustalenia niż wiek biologiczny, psychiczny i społeczny, choć te zdaniem gerontologów wyznaczaja dokładniej stopień zaawansowania starości ${ }^{6}$. I tak w biegu życia można wyróżnić:

I - okres poznawania świata i przygotowań do pełnienia ról biologicznych, społecznych i zawodowych - pierwsze 30 lat życia jednostki,

II - okres twórczy, podzielony na dwa 15-letnie podokresy: wieku średniego (30-45 lat) i wieku dojrzałego (45-60 lat).

\footnotetext{
${ }^{2}$ P. Huget, Poczucie sensu życia ludzi młodych i ich stosunek do starości, „Państwo i Społeczeństwo”, 2007, nr 3, s. 107.

${ }^{3}$ Ibidem.

${ }^{4}$ J. Zalewska, Cztowiek starszy - aktywny podmiot polityki spotecznej? Koncepcja upodmiotowienia a pluralizm rynkowy, w: M. Racław (red.), Publiczna troska, prywatna opieka, społeczności lokalne wobec osób starszych, Warszawa 2011, s. 53.

${ }^{5}$ B. Szatur-Jaworska, P. Błędowski, M. Dzięgielewska, Podstawy gerontologii spotecznej, Warszawa 2006, s. 45.

${ }^{6}$ A. Leszczyńska-Rejchert, Cztowiek starszy i jego wspomaganie - $w$ strone pedagogiki starości, Olsztyn 2007, s. 40.
} 
III - okres starości, także podzielony na dwa 15-letnie podokresy: tak zwanego III wieku (young old - 60-75 lat) oraz podokres starości dojrzałej (old old, 75-90 lat),

IV - okres długowieczności - powyżej 90 lat aż do końca życia (oldest old, long life $)^{7}$.

Do zmian biologicznych występujących $\mathrm{w}$ fazie starości należą: zmiany w wyglądzie zewnętrznym i w funkcjonowaniu zmysłów, zaburzenia funkcjonowania poszczególnych układów organizmu, ograniczenie i zmienione przejawy seksualności, różnego typu schorzenia. Przeprowadzone badania biologów wykazuja, że długość życia jednostek jest zależna od „dziedzictwa genetycznego", jakie otrzymuja od swoich przodków. Należy pamiętać, że na stan zdrowia podczas starości wpływaja nie tylko czynniki biologiczne, ale i społeczno-kulturowe. Na fizyczną kondycję seniorów wpływaja bowiem odgrywane we wcześniejszych latach życia role społeczne, styl życia, narażenie na czynniki chorobotwórcze (stres, warunki pracy, stan środowiska przyrodniczego). Już od dzieciństwa pracujemy na to, kiedy zaczniemy się starzeć, w jakim tempie będzie przebiegał ten proces i jakie będą jego przejawy.

W psychologii przez wiele lat dominował deficytowy model starości. Starzenie się było utożsamiane ze strata, brakiem sprawności psychofizycznych, rozpadem, z chorobami, niezdolnością osiagnięć. Zakładano, że wraz $\mathrm{z}$ wiekiem następuje obniżenie intelektualnej zdolności uczenia się i osiagnnięć. Współcześnie koncepcja ta jest negowana przez teorie psychologiczne, które uznaja, że na każdym etapie rozwoju możliwe jest stałe doskonalenie się i samorozwój. Wśród nich najbardziej znana jest teoria szkoły bońskiej, zakładająca, że starość nie jest tylko efektem przeżytych lat, lecz głównie ukształtowanym obrazem siebie, połączonym z cechami osobowości, aktywnością życiową i ze stanem zdrowia.

Podstawowym zadaniem rozwojowym każdej fazy życia jest osiągnięcie stanu równowagi i przystosowania. Zadaniami rozwojowymi dla starości sa między innymi: zaakceptowanie własnej zależności (choć we wcześniejszych fazach życia liczy się właśnie niezależność i samodzielność), sporządzenie bilansu życiowego, pogodzenie się z nieuchronnością procesu starzenia się, pozytywne rozwiązanie dylematu integralności i rozpaczy w taki sposób, by osiągnąc mądrość i podchodzić z dystansem do życia, zaakceptować śmierć ${ }^{8}$.

\section{OPIS STANU ZDROWIA OSÓB STARSZYCH}

Zgodność wieku metrykalnego z wiekiem czynnościowym świadczy o prawidłowej, fizjologicznej starości, natomiast „,starszy” wiek czynnościowy od wieku metrykalnego jest wyznacznikiem starości przedwczesnej - patologicznej. W dzisiejszych czasach coraz rzadziej występuje starość fizjologiczna. Starość patologiczna $\mathrm{w}$ nierozerwalny sposób powiązana jest $\mathrm{z}$ chorobami, które

7 Z. Szarota, op. cit., s. 25.

${ }^{8}$ B. Szatur-Jaworska, P. Błędowski, M. Dzięgielewska, op. cit., s. 54-57. 
sprzyjają rozchwianiu równowagi organizmu, czego skutkiem jest upośledzenie sprawności człowieka, zaburzenia w jego funkcjonowaniu i przystosowaniu. Seniorzy odznaczaja się zmniejszoną odpornością i osłabieniem reakcji obronnych, niestabilnościa środowiska wewnętrznego, występuje u nich polipatologia (współistnienie wielu chorób). Skuteczne leczenie chorób utrudniają zacierające się charakterystyczne objawy chorobowe albo występowanie objawów nietypowych.

Choroby seniorów powiązane z procesem starzenia się można podzielić na trzy grupy: choroby wieku wcześniejszego, nękające dane osoby od wielu lat; choroby, które pojawiły się na starość, ale nie wynikają z procesu starzenia się; procesy patologiczne spowodowane głównie starzeniem się. Stan zdrowia społeczeństwa uwarunkowany jest poziomem życia, nawykami zdrowotnymi, warunkami epidemiologicznymi, stanem środowiska przyrodniczego i wieloma innymi czynnikami, dlatego też dolegliwości typowe dla starości są różne w poszczególnych krajach. Międzykulturową cechą łącząca seniorów jest natomiast występowanie chorób przewlekłych. Choroby przewlekłe charakteryzują się długotrwałością, pogorszeniem sprawności, uzależnieniem, następstwami psychospołecznymi, staja się problemem współczesnej opieki. Coraz więcej przewlekle chorych seniorów zwiększa grupę chroników geriatrycznych (tj. osób wymagających opieki długotrwałej, początkowo ambulatoryjnej, później domowej, uzależnionych od pomocy innych). Najczęściej występującymi chorobami przewlekłymi sa: choroba nadciśnieniowa, reumatoidalne zapalenia stawów, choroby kości, niedokrwienna choroba serca. Wiele osób starszych choruje także na miażdżycę, która często rozpoczyna się w młodości, przez wiele lat rozwija się w ukryciu, a na starość daje o sobie znać poprzez zawały serca czy udary mózgu. Natomiast zmiany w obrębie mózgu prowadzą do ciężkich i nieuleczalnych schorzeń, jak demencja, choroba Parkinsona czy choroba Alzheimera. Ciężka, przewlekła choroba może doprowadzić do stanu tak zwanego niedołęstwa starczego (jest to stan, w którym senior staje się niezdolny do wykonywania codziennych czynności życiowych, wymaga stałej opieki i pomocy). Niedołęstwo starcze może też występować bez wyraźnych przyczyn chorobowych lub być efektem nagromadzenia się różnych schorzeń. Starzenie się jest również czynnikiem zwiększającym ryzyko chorób nowotworowych ${ }^{9}$.

Ważne jest też umiejętne rozpoznawanie i przeciwdziałanie patologii związanej z zaburzeniami zdrowia psychicznego. Otępienie lub choroba psychiczna często zmieniają całą psychikę osoby starszej, co prowadzi do konieczności stałej opieki nad tą osobą. Odchylenia umysłowe na ogół rozwijają się stopniowo, początkowo mogą manifestować się przez pewne dziwactwa lub przez nasilenie cech charakteru, którymi dana osoba odznaczała się przez całe życie. Wśród zaburzeń psychicznych najczęściej występują demencja i depresja ${ }^{10}$.

Zatem stan zdrowia osób starszych zależy od wielu czynników: poziomu wykształcenia, wysokości dochodów, stylu życia, miejsca zamieszkania, dostępności i możliwości korzystania z usług medyczno-rehabilitacyjnych i higie-

\footnotetext{
9 Ibidem, s. 48-51.

${ }^{10}$ A. Leszczyńska-Rejchert, op. cit., s. 42-45.
} 
nicznych oraz socjalnych. Kondycja fizyczna emerytów w znacznym stopniu decyduje o samopoczuciu, autonomii, aktywności, w efekcie o jakości życia w okresie starości. Pogarszające się zdrowie negatywnie wpływa na możliwości fizyczne i stan psychiki. Choroby somatyczne wywołuja chroniczne bóle, a choroby psychiczne - degradację psychiczna. Ponadto często zły stan zdrowia zmusza do przerwania pracy, utrudnia prowadzenie domu i wykonywanie podstawowych czynności życiowych, a także ogranicza mobilność (,uwięzienie” w swoim domu). Wszystko to wpływa na zmniejszenie się liczby kontaktów z innymi ludźmi i utrudnia aktywny udział w życiu społecznym. Sprzyja to złemu samopoczuciu, wycofywaniu się z życia, bierności, frustracji, uzależnieniu od pomocy innych. Bardzo często problemy zdrowotne osób starszych występuja razem z problemami materialnymi i mieszkaniowymi, co prowadzi do jeszcze większej apatii i rezygnacji.

Paradoksalnie, źródeł problemów zdrowotnych osób starszych można upatrywać w postępie medycyny, dzięki któremu duża liczba słabych i chorych osób wkracza w ostatnią fazę życia. Jednocześnie medycyna jest bezsilna wobec chorób zwyrodnieniowych i miażdżycy. Poza tym działania w zakresie pomocy społecznej i rehabilitacji nie sa na najlepszym poziomie w Polsce, co pogłębia problemy zdrowotne seniorów. Wspomniana zła sytuacja finansowa emerytów i rencistów, niewystarczająca infrastruktura społeczna w ochronie zdrowia i pomocy społecznej, niekorzystna sytuacja służby zdrowia (utrudniony dostęp do lekarzy, sprzętu) także ograniczają możliwości leczenia ${ }^{11}$. „Codzienność to mała dostępność do opieki podstawowej, nie wspominając o poradniach innych specjalności niż medycyna rodzinna czy dostępie do opieki szpitalnej; to niejasno określony zakres porad specjalistycznych i oczekiwań od lecznictwa szpitalnego; to kliniczne traktowanie objawów, »zapominanie« o profilaktyce, słabo akcentowane znaczenie tych najtrudniejszych, ale najbardziej efektywnych zmian stylu życia. Realność to zagubiony w labiryncie procedur pacjent (»zagubiony« wprost proporcjonalnie do jego wieku), otrzymujący receptę, zażywający kolejny lek, nieinformowany, nieedukowany, stojący na rozdrożu wielokierunkowych, niejednokrotnie sprzecznych komunikatów $\mathrm{z}$ różnych poradni, od wielu lekarzy"12.

\section{LECZENIE SENIORÓW}

Przedstawiona wyżej analiza stanu zdrowotnego seniorów wskazuje na złożoność ich sytuacji zdrowotnej, która wymaga kompleksowego podejścia. Najczęściej jednak starsi pacjenci sa leczeni równolegle przez wielu lekarzy specjalistów. Generuje to ogromne koszty dla systemu, który w swoim obecnym kształcie nie jest w stanie zapewnić odpowiedniej opieki geriatrycznej i rehabilitacji osobom w zaawansowanym wieku. A przecież ,powszechny dostęp do

\footnotetext{
11 Ibidem, s. 72-75.

${ }^{12}$ D. Kurpas, Kiedy starość nie jest równoznaczna z zależnościa $i$ samotnościa - punkt widzenia lekarza rodzinnego, w: S. Rogala (red.), Starość i jej konsekwencje społeczno-rodzinne, Opole 2010, s. 48.
} 
rehabilitacji dla osób w wieku poprodukcyjnym pozwoliłby w wielu przypadkach uniknąc utraty sprawności do wykonywania codziennych czynności” ${ }^{13}$. Choroba, szczególnie nieleczona, może prowadzić do niepełnosprawności i niesamodzielności - niezwykle istotne jest takie zorganizowanie systemu opieki zdrowotnej, żeby pacjenci mieli możliwość szybkiego zdiagnozowania i wyleczenia choroby. Wielu przypadków niesamodzielności i niepełnosprawności można by uniknąć, gdyby „,w leczeniu pacjenta punktem wyjścia były jego potrzeby wynikające ze stanu zdrowia, a nie »podział « schorzeń według kompetencji, specjalności i dyscyplin medycznych" ${ }^{14}$.

Większość krajów już dawno zrozumiała pilną konieczność rozwoju geriatrii i badań nad starzeniem. Geriatria wywodzi się z interny i zajmuje się stanami wielochorobowymi, typowymi dla okresu starzenia się, oraz ich skutkami funkcjonalnymi. Spośród innych dziedzin medycyny geriatrię wyróżnia kompleksowe podejście do pacjenta i całościowa ocena jego stanu zdrowia - opieka zdrowotna nad osobą starszą wymaga bowiem holistycznej analizy nie tylko stanu fizycznego pacjenta, ale także funkcjonalnego i społeczno-ekonomicznego. Rozwój geriatrii może wpłynąć na zmniejszenie kosztów leczenia pacjentów starszych. Stosowanie całościowej oceny geriatrycznej dla pacjenta oznacza precyzyjną diagnozę, zmniejszenie umieralności, poprawę kondycji fizycznej i umysłowej, ograniczenie liczby przyjmowanych leków. Dla systemu przynosi to korzyści w postaci redukcji zbytecznych świadczeń (ambulatoryjnych i hospitalizacyjnych). Należy podkreślić, że leczeniu szpitalnemu poddawane sa głównie dwie grupy pacjentów: małe dzieci do 4 roku życia oraz osoby w wieku powyżej 50 lat. Osoby powyżej 80 roku życia stanowią 26,2\% wszystkich pacjentów leczonych $\mathrm{w}$ szpitalu, wraz $\mathrm{z}$ wiekiem wydłuża się również czas pobytu w szpitalu. Leczenie osób starszych generuje ogromne koszty, mimo że w ślad za nimi nie idzie poprawa jakości świadczonych usług ani tym bardziej wzrost ich dostępności. Nadal wiele osób potrzebujących konsultacji lekarskiej rezygnuje $\mathrm{z}$ wizyty $\mathrm{u}$ lekarza $\mathrm{z}$ powodu braku pieniędzy czy długiego czasu oczekiwania na poradę. Paradoksalnie, najczęściej rezygnują osoby bardzo poważnie chore i niepełnosprawne ${ }^{15}$.

\section{OPIEKA GERIATRYCZNA W POLSCE - POSTULATY I RZECZYWISTOŚ́}

System opieki zdrowotnej w obecnym kształcie jest zupełnie niedostosowany do potrzeb populacji, ponieważ opiera się na ,zdezintegrowanych, rozproszonych i niespójnych świadczeniach". Standardami, które powinny znaleźć zastosowanie w leczeniu geriatrycznym są: powszechność, jakość, dostępność

\footnotetext{
${ }^{13}$ Ibidem, s. 105.

${ }^{14}$ Założenia polityki ludnościowej Polski 2012, Projekt, Warszawa 2012, http://www.stat.gov.pl/ cps/rde/xbcr/gus/POZ_projekt_zalozenia_polityki_ludnosciowej_w_polsce_rrl.pdf, s. 82 .

15 Założenia polityki ludnościowej Polski 2012, Projekt, Warszawa 2012, http://www.stat.gov.pl/ cps/rde/xbcr/gus/POZ_projekt_zalozenia_polityki_ludnosciowej_w_polsce_rrl.pdf, s. 113.
} 
i kompleksowość zaspokajania złożonych potrzeb zdrowotnych osób starszych ${ }^{16}$. Geriatria, dysponująca standardami całościowej oceny stanu zdrowia pacjenta, jest $\mathrm{w}$ stanie zastąpić wiele wstępnych interwencji wąskospecjalistycznych. Pozwala to nie tylko uniknąc strat związanych $\mathrm{z}$ wizytami u wielu innych specjalistów, ale także pozwala lepiej przygotować pacjenta do interwencji innych specjalistów, ,,a przez to redukować farmakoterapię i oszczędzać środki w systemie ochrony zdrowia"17. Doświadczenia wielu krajów pokazują, że główną bolączką systemu opieki zdrowotnej nad starszymi pacjentami jest jego niespójność, brak odpowiedniej koordynacji oraz brak komunikacji pomiędzy lekarzami zajmującymi się jednym pacjentem ${ }^{18}$.

Problemem, który często towarzyszy chorobom osób starszych, jest zjawisko polipragmazji (sytuacja, w której chory przyjmuje więcej niż kilka leków jednocześnie, co prowadzi do znacznego zwiększenia skutków ubocznych stosowanych leków). Polipragmazja w dwojaki sposób generuje dodatkowe koszty leczenia: po pierwsze - koszty związane z zakupem kolejnych leków (często bardzo drogich), po drugie - koszty związane z leczeniem niepożądanych działań ubocznych, gdyż objawy związane z błędami jatrogennymi są przyczyną $20 \%$ wszystkich hospitalizacji osób starszych. Przyczyną takiego stanu jest między innymi brak koordynacji opieki wysokospecjalistycznej z podstawowa opieką zdrowotną. Lekarze pierwszego kontaktu nie są przygotowani do opieki geriatrycznej, często osoby starsze są kwalifikowane do wysokospecjalistycznych procedur bez całościowej geriatrycznej analizy przeciwwskazań. Ewentualne powikłania są dodatkowym obciążeniem finansowym dla systemu.

Wyliczono, że różnica kosztów, jakie ponosi Narodowy Fundusz Zdrowia za roczne świadczenia dla osoby w wieku 60 lat i więcej, po ukończonej hospitalizacji w oddziale geriatrycznym w porównaniu z oddziałem chorób wewnętrznych stanowi wartość 1747 zł. W skali całego kraju można by uzyskać oszczędność na poziomie 7957585 zł rocznie. Niestety, nadal brak podstaw prawnych porządkujących rodzaj, sposób i zakres świadczeń, jakie powinny być udzielane w nowej dziedzinie chorób wewnętrznych, którą jest geriatria ${ }^{19}$.

Geriatria została uznana za priorytetową dziedzinę medycyny już w $2003 \mathrm{r}$. w rozporządzeniu Ministra Zdrowia z 22 grudnia 2003 r. w sprawie uznania dziedzin medycyny za priorytetowe (Dz. U. 2004, Nr 1, poz. 7) - wymieniona została zaraz po epidemiologii. Rozporządzenie to zostało zastapione w 2009 r.

\footnotetext{
${ }^{16}$ Jak ocenił Zespół ds. Geriatrii przy Ministrze Zdrowia; Założenia polityki ludnościowej Polski 2012, Projekt, Warszawa 2012, http://www.stat.gov.pl/cps/rde/xbcr/gus/POZ_projekt_zalozenia_ polityki_ludnosciowej_w_polsce_rrl.pdf, s. 113.

${ }_{17}$ Uzasadnienie projektu rozporządzenia Ministra Zdrowia w sprawie standardu postępowania przy udzielaniu świadczeń zdrowotnych z zakresu geriatrii http://www.mz.gov.pl/wwwmz/index?mr= $\mathrm{q} 491 \& \mathrm{~ms}=383 \& \mathrm{ml}=\mathrm{pl} \& \mathrm{mi}=383 \& \mathrm{mx}=0 \& \mathrm{mt}=\& \mathrm{my}=0 \& \mathrm{ma}=015195$.

18 „Family caregivers reported lack of coordination within health care institutions as well as between institutions. Within hospitals, for example, family caregivers said that doctors often do not talk to each other about patients they have in common"-A. Brookman, M. Harrington, Family Caregivers: A Shadow Workforce in the Geriatric Health Care System?, ,Journal of Health Politics, Policy and Law” 32, 2007, nr 6 (December), s. 1015.

${ }^{19}$ Uzasadnienie projektu rozporządzenia Ministra Zdrowia w sprawie standardu postępowania przy udzielaniu świadczeń zdrowotnych z zakresu geriatrii http://www.mz.gov.pl/wwwmz/index?mr= $\mathrm{q} 491 \& \mathrm{~ms}=383 \& \mathrm{ml}=\mathrm{pl} \& \mathrm{mi}=383 \& \mathrm{mx}=0 \& \mathrm{mt}=\& \mathrm{my}=0 \& \mathrm{ma}=015195$.
} 
rozporządzeniem Ministra Zdrowia z 21 maja 2009 r. w sprawie uznania dziedzin medycyny za priorytetowe (Dz. U. 2009, Nr 84, poz. 709) - tu wymieniona została na 4 miejscu, zaraz po anestezjologii i intensywnej terapii, chirurgii onkologicznej i epidemiologii. W rozporządzeniach tych dostrzeżono wage opieki geriatrycznej dla kondycji zdrowotnej społeczeństwa. Były to chyba jedyne działania, jakie ustawodawca podją $\mathrm{w}$ tym obszarze. Temat geriatrii w systemie ochrony zdrowia jest konsekwentnie pomijany. W uzasadnieniu projektu rozporządzenia Ministra Zdrowia w sprawie standardu postępowania przy udzielaniu świadczeń zdrowotnych z zakresu geriatrii (przekazanym do uzgodnień zewnętrznych 19 maja 2010 r.) wskazano, że obowiązujące w systemie ochrony zdrowia prawodawstwo nie daje osobie starszej szczególnych przywilejów oraz że oczekuje się, iż poprawa jakości świadczeń skierowanych do osób w wieku powyżej 60 lat przyniesie nie tylko korzyści społeczne tym osobom, ale także pozwoli na bardziej racjonalne wykorzystanie środków finansowych pozostających w dyspozycji podmiotów działających w systemie ochrony zdrowia. Optymalizacja opieki ma zredukować jej koszty, badania z zakresu ekonomiki zdrowia i farmakoekonomiki dowodzą, że specjalistyczna opieka medyczna nad osobami w wieku powyżej 60 lat wydłuża okres względnie dobrego stanu zdrowia tych osób i racjonalizuje wydatki na świadczenia opieki zdrowotnej i leczenie farmakologiczne.

W Narodowym Programie Zdrowia na lata 2007-2015, przyjętym uchwała Rady Ministrów z 15 maja 2007 r., dostrzeżono problem starzenia się społeczeństwa. Dział III Programu obejmuje ,Cele operacyjne dotyczące wybranych populacji” - między innymi ,Tworzenie warunków do zdrowego i aktywnego życia osób starszych" (cel operacyjny $\mathrm{nr}$ 9). W ramach tego celu do $2015 \mathrm{r}$. spodziewa się osiągnąc następujące efekty: propagowanie idei ,aktywnego starzenia się", uzyskanie przez osoby starsze poczucia pełni zdrowia, bezpieczeństwa i aktywnego uczestnictwa w życiu gospodarczym, kulturalnym, społecznym i politycznym, zmniejszenia występowania niepełnosprawności, chorób przewlekłych i przedwczesnych zgonów w populacji osób powyżej 60 roku życia, zmniejszenia rozpowszechniania czynników ryzyka związanych z chorobami niezakaźnymi w populacji osób starszych. Jednocześnie wskazano na główne zadania w tym obszarze spoczywające na organach państwowych. Po stronie administracji rządowej wyznaczono następujące zadania: promocja zdrowia i zapobieganie chorobom w ciagu trwania całego życia, budowa i implementacja programów zdrowotnych nakierowanych na tworzenie warunków do aktywnego fizycznie i psychicznie stylu życia osób powyżej 60 roku życia, tworzenie rozwiązań systemowych umożliwiających opiekę nad osobą starszą $\mathrm{i} /$ lub niepełnosprawna w środowisku zamieszkania z poszanowaniem jej praw i zapewnieniem najwyższej z możliwych jakości usług opiekuńczo-leczniczych, tworzenie rozwiązań prawno-administracyjnych sprzyjających rozwojowi prozdrowotnego stylu życia przez uruchomienie mechanizmów ekonomicznych, skłaniających do zwiększenia podejmowania działań indywidualnych na rzecz aktywności fizycznej, podejmowania działań systemowych w kierunku zapewnienia ochrony, bezpieczeństwa i poszanowania godności osobistej osób starzejących się oraz podejmowanie działań na rzecz powszechnego i równego dostępu 
do świadczeń zdrowotnych, w tym leków dla osób starszych. Administracji samorządowej wyznaczono działania zmierzające do: umacniania działań na rzecz stworzenia przyjaznego dla wieku i bezpiecznego środowiska bytowego, zmniejszenia czynników ryzyka związanych z chorobami i wspomaganie czynników pozytywnych dla zdrowia występujących w środowisku zamieszkania, uaktywnienia szkoleń i edukacji osób, które mają bezpośredni wpływ na tworzenie prozdrowotnych zachowań w populacji osób powyżej 50 roku życia, aktywizacji środowisk lokalnych w podejmowaniu działań kształtujących zdrowy styl życia populacji osób powyżej 50 roku życia. Oczekiwane korzyści zdrowotne to zmniejszenie liczby niepełnosprawnych w grupie powyżej $60 \mathrm{roku}$ życia, zmniejszenie liczby zgonów w populacji powyżej 60 roku życia, zmniejszenie liczby chorych na choroby niezakaźne w populacji powyżej 60 roku życia, wydłużenie liczby lat życia wolnych od wszelkich dolegliwości oraz wydłużenie przeciętnego dalszego trwania życia.

Przyjęte założenia mają niezwykle szeroki zakres - od zmian dotyczących rozwiązań instytucjonalno-prawnych po edukację osób starszych. Jednakże Narodowy Program Zdrowia nie koresponduje z przyjętymi przez Ministra Zdrowia programami zdrowotnymi - w 2012 r. nie uwzględniono w nich programu adresowanego głównie dla osób starszych ${ }^{20}$. Oczywiście, medycyna transplantacyjna czy monitorowanie stanu zdrowia jamy ustnej objęte programami Ministra Zdrowia dotyczą całej populacji, w tym również osób starszych, brak programu typowo geriatrycznego skłania jednak do refleksji, że realizacja założeń zawartych w omawianym celu 9 Narodowego Programu Zdrowia przebiega wyjątkowo niesprawnie. Podobnie analiza wszystkich programów zdrowotnych państwa realizowanych od 2000 r. pokazuje, że żaden z realizowanych programów nie był skierowany głównie do osób starszych.

Niestety w praktyce świadczenia udzielane przez lekarzy geriatrów stanowią promil wszystkich świadczeń. Osoby starsze są dyskryminowane w systemie ochrony zdrowia w zakresie procedur diagnostycznych i leczniczych. Do kontraktowania świadczeń geriatrycznych NFZ nie dofinansowuje kosztów czasu pracy interdyscyplinarnego zespołu niezbędnego w diagnostyce geriatrycznej. Fundusz pokrywa koszty hospitalizacji z powodu jednej choroby. Ewentualna hospitalizacja dzienna oraz domowe wizyty geriatry sa przez Fundusz pomijane. Nie powinno więc dziwić, że w 2007 r. liczba udzielonych świadczeń geriatrycznych stanowiła $0,04 \%$ wszystkich porad specjalistycznych. Seniorzy, którzy chca poprawić swój stan zdrowia, są więc skazani na równoległe leczenie u wielu specjalistów. Starsi pacjenci często nie pamiętaja, jakie leki i w jakich dawkach zostały im zaordynowane, nie mają dostępu do kompletnej dokumentacji medycznej (która znajduje się w różnych poradniach). Taka sytuacja z całą pewnością nie sprzyja efektywnemu leczeniu seniorów.

Komentarza wymaga również zasób osobowy wykształconych lekarzy specjalistów - w Polsce jest obecnie 150 lekarzy geriatrów (czyli 1 na 300000 pacjentów), jednak nie wszyscy pracuja jako geriatrzy (na marginesie należy

${ }^{20}$ Zob. http://www.mz.gov.pl $/ \mathrm{wwwmz} / \mathrm{index} ? \mathrm{mr}=\mathrm{b} 3 \& \mathrm{~ms}=0 \& \mathrm{ml}=\mathrm{pl} \& \mathrm{mi}=0 \& \mathrm{mx}=0 \& \mathrm{mt}=\& \mathrm{my}=$ $246 \& \mathrm{ma}=019000$. 
dodać, że z 12 uczelni medycznych w Polsce tylko na 4 wykłada się geriatrię) $)^{21}$. Na 10000 mieszkańców przypada 0,7 łóżka na oddziale geriatrycznym (496 łóżek na cały kraj) ${ }^{22}$. Istnienie nielicznych oddziałów geriatrycznych i tak jest zagrożone - ze względu na poszerzony zakres diagnostyki i terapii geriatrycznej oraz standardy leczenia geriatrycznego wycena punktowa procedur geriatrycznych jest niedoszacowana. Oddziały te przynoszą często straty zakładom opieki zdrowotnej. Medycyna geriatryczna w Polsce przeżywa poważny kryzys, $\mathrm{w}$ kraju działaja aktualnie 34 poradnie ( $\mathrm{w}$ ramach ambulatoryjnej opieki specjalistycznej) oraz 35 oddziałów geriatrycznych (leczenie stacjonarne) ${ }^{23}$. Utopijne sa też założenia o rozwoju lecznictwa w domu pacjenta. Oczywiste, baza lecznicza w takim wymiarze nie odpowiada faktycznym potrzebom. Należy jeszcze raz podkreślić, że podjęcie wielokierunkowych działań w zakresie rozwoju geriatrii może zahamować lawinowy wzrost kosztów opieki zdrowotnej, a „wprowadzenie geriatrii do systemu ochrony zdrowia może wpłynąc na poprawę jakości życia i dobrostanu osób starszych. Istota geriatrii jest bowiem upodmiotowienie pacjenta - traktowanie go holistycznie jako całość psychofizyczną, a nie konglomerat wielu chorób lub przedmiot opieki paliatywnej bądź długoterminowej”24.

\section{EKONOMICZNE SKUTKI STAROŚCI}

Starzenie się społeczeństwa ma doniosłe skutki dla finansów publicznych państwa. Osoby starsze i niesamodzielne często wymagają stałej opieki - osoba opiekująca się (a jest to najczęściej członek rodziny chorego lub osoba jej bliska) jest więc nieaktywna zawodowo. Taka sytuacja skutkuje nie tylko obniżeniem dochodów gospodarstw domowych, ale także wzrostem kosztów związanych $\mathrm{z}$ opieką. Równocześnie rosną wydatki budżetu państwa na zasiłki, renty, emerytury (należy nadmienić, że głównym powodem udzielania pomocy osobom starszym jest długotrwała choroba lub niepełnosprawność ${ }^{25}$ ). Koszty związane $\mathrm{z}$ ochrona zdrowia stanowia drugie pod względem wielkości, zaraz po wydatkach na utrzymanie mieszkania, źródło wydatków gospodarstw osób starszych. Masowo rosnące ubóstwo osób niezdolnych do dalszej pracy może skutkować albo obciążeniem rodzin kosztami utrzymania takich osób albo obciążeniem finansowym samorządów terytorialnych (szczególnie tych

21 „Jedna czwarta z nich [geriatrów] nie pracuje, w swojej dziedzinie, bo nie ma zatrudnienia, albo rezygnuje ze względu na niskie kontrakty z NFZ”, „Dziennik Gazeta Prawna” z 29 maja 2009 r., http:// praca.gazetaprawna.pl/artykuly/321532,kopacz_beda_zmiany_wycen_swiadczen_w_geriatrii.html.

${ }^{22}$ Dane z 2007 r., http://www.stat.gov.pl/cps/rde/xbcr/gus/POZ_projekt_zalozenia_polityki_ludnosciowej_w_polsce_rrl.pdf, s. 116.

${ }^{23}$ Dane z marca 2012 r., na podstawie Portalu Zakładów Opieki Zdrowotnej - http://www.rejestr zoz.gov.pl/RZOZ/.

${ }^{24}$ Założenia polityki ludnościowej Polski 2012, Projekt, Warszawa 2012, http://www.stat.gov.pl/ cps/rde/xbcr/gus/POZ_projekt_zalozenia_polityki_ludnosciowej_w_polsce_rrl.pdf, s. 120.

${ }^{25}$ M. Racław, „Zarzadzanie” osobami starszymi - przyczynek do dyskusji o lokalnej polityce spotecznej, w: eadem (red.), op. cit., Warszawa 2011, s. 24. 
z niekorzystną strukturą demograficzną mieszkańców) ${ }^{26}$. Zły stan zdrowia osób starszych w połączeniu z ograniczoną sprawnością i ograniczonym dostępem (lub wręcz jego brakiem) do usług ochrony zdrowia, niskimi dochodami, uboga konsumpcja, złymi warunkami mieszkaniowymi wpływa na społeczne wykluczenie osób starszych.

Przeciętna długość życia w Polsce w 2010 r. wyniosła 79,8 roku dla kobiety i 71,4 roku dla mężczyzny. Prognozy na 2035 r. wskazują wzrost przeciętnego dalszego trwania życia, odpowiednio, 82,9 i 77,127. Przedłużający się czas trwania życia skorelowany jest ze stopniowa utrata zdolności do samodzielnej egzystencji w zaawansowanym wieku ostatniej fazy życia. Wskazuje się na różne przyczyny niesamodzielności osób starszych: warunki życia, działania lub zaniechania działania systemu ochrony zdrowia, jego sprawną (lub niesprawna) organizację dostosowana (lub nie) do potrzeb osób starszych. „Osoby niesamodzielne to często „ofiary” nieskutecznego działania i wadliwej organizacji systemu opieki medycznej, braku zintegrowanej wielo- i wysokospecjalistycznej opieki nad pacjentem, przedłużających się proceduralnych postępowań w organizacji leczenia i rehabilitacji. Wielu przypadków niezdolności do samodzielnej egzystencji można byłoby uniknąć, gdyby w leczeniu pacjenta punktem wyjścia były jego potrzeby wynikające ze stanu zdrowia, a nie podział schorzeń według kompetencji, specjalności i dyscyplin medycznych" ${ }^{28}$.

Stan zdrowia w oczywisty sposób przekłada się na naszą aktywność zawodową. Ta z kolei wpływa na kondycję finansów publicznych. Dlatego reformie systemu emerytalnego powinna towarzyszyć reforma systemu ochrony zdrowia, który nie jest przygotowany na starzenie się polskiego społeczeństwa. Najnowsze doniesienia wskazuja, że Ministerstwo Finansów, przygotowując założenia do wprowadzanych zmian, korzystało z nieaktualnych danych przedstawionych przez GUS (w 2008 r.) i Eurostat (w 2010 r.), które zakładały, że do 2027 r. liczba Polaków zmaleje z 38,2 mln do 37,2 mln. Jak wiadomo, liczbę tę osiagnęliśmy już w 2011 r. - tylu rzeczywiście jest rezydentów (osób mieszkających w Polsce). Pozostały milion Polaków przebywa za granica, sa to głównie osoby w wieku prokreacyjnym - ich pieniądze nie zasilają FUS ani budżetów centralnego i terytorialnych. „Oznacza to, że za 15 lat na jednego pracującego będzie przypadało więcej emerytów niż założył rząd” ${ }^{29}$. A zatem realny jest scenariusz, w którym wydłużenie wieku emerytalnego do $67 \mathrm{roku}$ życia okaże się niewystarczające. Ustawodawca zdaje się też nie dostrzegać, że wydłużenie wieku emerytalnego może okazać się niemożliwe do zrealizowania „,z uwagi na znaczny udział osób w złym stanie zdrowia oraz o ograniczonej sprawności" ${ }^{30}$.

${ }^{26}$ Ibidem, s. 96 .

27 Założenia polityki ludnościowej Polski 2012, Projekt, Warszawa 2012, http://www.stat.gov.

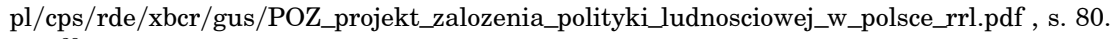

${ }^{28}$ Ibidem, s. 82.

29 J. J. Kowalski, Reforma reformy emerytalnej. Bo dane się zdezaktualizowaty, „Dziennik Gazeta Prawna" z 14 marca 2012 r., s. A1.

${ }^{30}$ Założenia polityki ludnościowej Polski 2012, s. 106. 


\section{PROFILAKTYKA GERONTOLOGICZNA}

Zapobieganie chorobom (a nie objawowe leczenie) i przygotowanie się do ostatniego etapu życia jest najlepszym rozwiązaniem problemów patologicznej starości. Jest to możliwe dzięki profilaktyce gerontologicznej (profilaktyce pomyślnego starzenia się) wdrażanej od najmłodszych lat życia, pozwalającej przygotować się do dobrej starości i opóźniającej proces starzenia się. $\mathrm{Na}$ początku należy uświadomić sobie, że czeka na nas w ostatniej fazie życia wiele zasadzek, między innymi: osamotnienie wynikające $\mathrm{z}$ odejścia dorosłych dzieci $\mathrm{z}$ domu rodzinnego, zaniechanie kontaktów $\mathrm{z}$ dotychczasowymi kolegami z pracy (w efekcie przejścia na emeryturę), rozluźnienie więzi towarzyskich z rówieśnikami, śmierć współmałżonka, „rozangażowanie się” społeczne i uczuciowe, alienowanie się, udręka osamotnienia. Aby uniknąć powyżej wymienionych niebezpieczeństw, powinno się w wieku emerytalnym utrzymywać życiową aktywność poprzez wykonywanie pracy „,cenionej i użytecznej”, rozwijanie swoich pasji i hobby, angażowanie się w działalność grup sąsiedzkich, życie towarzyskie, udział w spotkaniach osiedlowego klubu seniora czy w zajęciach oferowanych przez uniwersytet trzeciego wieku ${ }^{31}$, gdyż jedna z podstawowych cech wartościowego życia jest aktywność. Organizm człowieka przeznaczony jest właśnie do aktywności i działania. Równowaga w aktywności psychicznej i fizycznej jest podstawa dobrego zdrowia i bezbolesnego przejścia jednostki w trzecią fazę życia. Jeśli człowiek od lat młodzieńczych prowadził aktywne życie, to pierwsze oznaki starzenia pojawią się u niego znacznie później niż u biernych rówieśników ${ }^{32}$.

Przygotowanie do starości obejmuje pięć pól aktywności wychowanków: pole biologiczne, psychologiczne, intelektualne, społeczne i ekonomiczne. Poziom biologiczny związany jest z kształtowaniem nawyków higienicznego stylu życia (właściwe nawyki żywieniowe, zachęta do fizycznej aktywności, prewencja uzależnień). Drugie pole dotyczy pracy nad psychicznym dobrostanem jednostki (samopoznanie i akceptacja własnej osoby jako człowieka z wadami i zaletami, pozytywne myślenie o własnej przyszłości, wyznaczanie sobie celów, optymizm, zaakceptowanie starości jako naturalnej kolei rzeczy). Poziom intelektualny obejmuje rozwijanie $\mathrm{w}$ sobie otwartości i chęci poznania nowych rzeczy, nabywanie dodatkowych umiejętności, poszerzanie posiadanej już wiedzy. Celem wychowania jednostki powinno być nauczenie jej zagospodarowywania czasu wolnego, którego $\mathrm{w}$ starości człowiek ma w nadmiarze. W obrębie przygotowania społecznego chodzi o socjalizację jednostki i o społeczny protest przeciwko marginalizacji osób starszych i gerontofobii (postrzegania ludzi starych jako ciężaru społecznego). Przygotowanie ekonomiczne zawiera dbałość o własne oszczędności, racjonalne gromadzenie środków na ubezpieczenie zdrowotne i społeczne, dzięki czemu w przyszłości można będzie uniknąć ryzyka zależności od osób trzecich ${ }^{33}$.

${ }^{31}$ Z. Szarota, op. cit., s. 135-139.

${ }^{32}$ A. A. Zych, Człowiek wobec starości. Szkice z gerontologii społecznej, Warszawa 1995, s. 99.

${ }^{33}$ Z. Szarota, op. cit., s. 140-141. 
Kolejną droga do zdrowej i radosnej starości jest edukacja zdrowotna przygotowująca do starości. Za realizację celów edukacji zdrowotnej do starości odpowiedzialnych jest wiele podmiotów (rodzina, szkoła, służba zdrowia, media). System edukacji zdrowotnej do starości jest jednym z podsystemów w całym systemie edukacji zdrowotnej i rozumie się go jako dynamiczny układ powiązanych ze sobą pod względem celowym, funkcjonalnym i logicznym takich grup elementów, jak: osoby, procesy (nauczania, uczenia się), współczynniki (cele, treści, zasady, metody, formy). Głównym celem edukacji zdrowotnej do starości jest długa, pogodna i zdrowa starość. Powinno być to realizowane przez takie cele szczegółowe, jak: tworzenie warunków sprzyjających godnej i aktywnej starości, edukacja społeczeństwa w problematyce starzenia się i jego konsekwencji, promocja pozytywnego wizerunku starzenia się, organizacja i wspieranie organizacji wspomagających seniorów w wielostronnej aktywności. Takiej edukacji powinni podlegać przede wszystkim rodzice, dziadkowie, nauczyciele przedszkoli i szkół, lekarze rodzinni, geriatrzy, pielęgniarki, instytucje społeczne i kościelne oraz media. Edukacja zdrowotna do starości powinna trwać przez całe życie, a jej efektem powinny być pozytywne postawy wobec ludzi w podeszłym wieku ${ }^{34}$.

Edukacja zdrowotna jest komplementarnym elementem promocji zdrowia. Zgodnie ze swoimi założeniami edukacja zdrowotna dąży do poprawy i ochrony zdrowia poprzez stymulowane procesem uczenia się dobrowolne zmiany w zachowaniu jednostek. Działania te obejmuja podnoszenie poziomu wiedzy o zdrowiu, poradnictwo z zakresu zagrożeń zdrowia, budowanie wysokiej samooceny oraz samodzielności. Edukacja zdrowotna seniorów powinna mieć charakter działań holistycznych, obejmować fizyczne, społeczne i psychiczne aspekty zdrowia. Nie można ograniczać się tylko do działań zmierzających do wzmacniania zdrowia, zapobieganie chorobom i niepełnosprawności, ale należy uczyć ludzi, jak czerpać satysfakcję z życia mimo przeszkód oraz jak minimalizować czynniki negatywnie wpływające na stan zdrowia i jakość życia. Edukacja zdrowotna przygotowująca do starości i w starości niesie ze soba wiele korzyści. Można ich upatrywać w wymiarze jednostkowym (dla seniora, umożliwienie lepszego funkcjonowania w życiu oraz samodzielność w radzeniu sobie z pojawiającymi się problemami), w wymiarze rodzinnym (zdrowy i zadowolony senior jest pomocny swojej rodzinie), w wymiarze społecznym (zdrowi ludzie starsi są dobrymi pracownikami), ekonomicznym (profilaktyka chorób jest mniej kosztowna niż leczenie), w wymiarze relacji społecznych (zdrowy i radosny senior zmienia negatywne stereotypy o starości, co owocuje lepszą współpracą międzypokoleniową) ${ }^{35}$.

\section{ZAKOŃCZENIE}

W podsumowaniu można sformułować tezę o braku jakiejkolwiek przemyślanej polityki, zarówno na szczeblu centralnym, jak i lokalnym, wobec ochrony zdrowia osób starszych. Być może wynika to z zakorzenionego w społeczeństwie

${ }^{34}$ C. Lewicki, Edukacja zdrowotna do starości - systemowa analiza wybranych zagadnień, w: M. Kuchcińska (red.), Edukacja do i w starości, Bydgoszcz 2008, s. 183-193.

${ }^{35}$ E. Kościńska, Edukacja zdrowotna seniorów, w: M. Kuchcińska (red.), op. cit., s. 199-211. 
sposobu myślenia o opiece nad seniorami jako o obowiązku ciążącym nad rodziną i bliskimi seniora. W przypadku ochrony zdrowia seniorów ingerencja państwa w kształt systemu zdrowia jest konieczna - mimo że starzenie się jest naturalnym etapem, procesem fizjologicznym, któremu nie zawsze towarzyszy choroba. Potrzeby zdrowotne osób starszych nie znajdują odzwierciedlenia $\mathrm{w}$ sposobie organizacji systemu zdrowia. Podejście do pacjenta seniora powinno uwzględniać jego specyficzny stan zdrowia, charakteryzujący się często wielochorobowością i przewlekłością. Dlatego konieczny wydaje się postulat rozwoju geriatrii i personalizacji medycyny. Przyniesie to wymierne efekty $\mathrm{w}$ postaci poprawy stanu zdrowia społeczeństwa oraz pozwoli zredukować koszty leczenia pacjenta. Zmianom w systemie ochrony zdrowia towarzyszyć jednak musi zmiana w sposobie myślenia o starości. Edukacja społeczeństwa w zakresie starości powinna być wielowymiarowa - musi mieć miejsce na wszystkich etapach rozwoju człowieka i ,,powinna polegać na uświadamianiu całemu społeczeństwu nie tylko problemów i praw ludzi starych, ale przede wszystkim pozytywnych aspektów starości”36.

mgr Maria Pieprzyk

Uniwersytet im. Adama Mickiewicza $w$ Poznaniu

pieprzyk.maria@gmail.com

mgr Paulina Pieprzyk

Uniwersytet im. Adama Mickiewicza $w$ Poznaniu

pieprzyk@amu.edu.pl

THE ELDERLY IN THE HEALTH CARE SYSTEM

Summary

Two major socioeconomic trends are currently changing the terrain of the elderly care - the population is ageing and the geriatric health care system is under an increasing strain. This will soon pose serious challenges for the public health system along with the state budget and family finances. Healthy ageing must become a priority objective for both the population and personal health services and to address the task will require innovative prevention programming.

Despite the rising health care costs, the public health care system is poorly managed, fragmented and depersonalised. The ageing of the population means that more senior citizens will need care for longer periods of time, and the strain on the health care system will continue to intensify. Already today many health care institutions have a limited capacity to respond adequately to the needs of the ageing population. What is more, geriatric care differs from standard adult health care because it focuses on the unique needs of the elderly person. The aged body is physiologically different from the younger adult body, and in the old age the decline of various organ systems becomes more manifest.

${ }^{36}$ B. Szmigielska, Starość w wypowiedziach mtodzieży i dorostych, „Państwo i Społeczeństwo” 2007, nr 3, s. 105 . 